\title{
TRANSPHONIC SOUNDS \\ Commercial radio music in a shared urban environment
}

Urban acoustic environments are composed of acoustic and electroacoustic sound events. Alongside typical everyday city sounds from vehicles, human beings, electric appliances and other machinery, the musical or non-musical sounds emitted by different sources occupy public and semi-public spaces.

A music source that is preferred significantly more in shops and enterprises than in any other location is a public service or commercial radio channel (Teosto 2012). According to previous research on Finnish enterprises regarding their use of background music, it is somewhat evident that the music contents of commercial radio station broadcasts, as defined by the economic and cultural motives of their owners and employees, are manifested sonically in the urban space, thus contributing to the overall characteristics of various shared acoustic spaces, whether mobile or sedentary (Uimonen 2009).

However, sonically manifested economic and cultural motives do not necessarily meet the preferences of each urban dweller within the range of the radio station's transmitter, as pointed out in the research (Uimonen 2009). The research examined the relationship among the construction of contemporary urban acoustic environments, popular music and the cultures of radio music broadcasts, and it was inspired by letters to the editor published in a Finnish newspaper expressing the diverse opinions of commuters, who were exposed to mainly rock and popular music on public transportation. Letters to the editor also initiated the research questions for the study, which concentrate on matters such as on what 
grounds radio stations select their music contents, who is in charge of music selection and what the implications are of radio stations' music selections for the construction of different urban spaces. In addition, the economic, legislative and cultural contexts that set the stage for commercial radio enterprises, including whether this has an effect on the urban sonic environment, were studied.

With the help of statistics provided by the International Federation of the Phonographic Industry (IFPI) Finland, it was possible to reconstruct the actual electroacoustic environments of local public transportation and to clarify in detail what the music content was like at a given time of day. The research was put in context with the help of the three-year study of the music contents of individual commercial radio stations in Finland. The empirical data in this study consisted of interviews conducted with radio station personnel on the music selection process, including managing directors, journalists and show hosts. (Uimonen 2011.)

The recent centralised ownership of commercial radio stations suggests a need for a continuation study on music contents and their effect on the shared sonic environment in urban settings. The aforementioned questions of the study will also be answered in this research putting emphasis on further theorisation to clarify the topic in more detail. This article also seeks to answer whether music content has changed during recent years and to further elaborate theoretically on the concepts of transphonic and ubiquitous listening, referring to both diverse everyday and everyplace listening enabled by contemporary consumer music technology (Kassabian 2002; Uimonen 2005).

The theoretical concepts of transphonic and ubiquitous listening will be outlined and clarified in the first section of the article. This will be followed by information on how contemporary urban spaces and radio music cultures are intertwined, including a description of commercial radio stations and how they select and standardise their music contents. This will be clarified by a case study on a radio station called Radio 957. Founded in Tampere in 1985 and being among the first commercial Finnish stations, it has changed its ownership, name and style over the years. Within 30 years, this formerly local radio station and its local transmitting area have transitioned to become a member of a semi-national radio group called Radio City, which mainly broadcasts mainstream rock in various towns and cities. 
In addition, this case study will shed light on how music content is related to overall changes in radio business and how this affects not only the local soundscape but also the different sonic environments on a semi-national level. The case study is followed by an analysis of letters to the editor of the local newspaper Aamulehti in relation to the radio music culture of Radio 957. Finally, this article will outline the implications of radio broadcasters' processes of selecting music for urban acoustic spaces.

\section{Transphonia, ubiquitous listening and radio music culture}

Some of the first scholarly attempts to study sonic environments and urban spaces were initiated at the Communications Department of Simon Fraser University in Vancouver. Soundscape studies and research projects were influenced by the environmental activism of the 1970s. To raise awareness on the issues of soundscape, several pedagogical actions were taken, including publishing educational booklets and advocating listening.

Certain concepts introduced were developed intentionally to be provocative to stir up discussion; sound imperialism referred to loud Western colonialism, which manifested in, for example, aircraft noise. Schizophonia was used to describe a "split between an original sound and its electro-acoustic reproduction", and it was introduced by composer R. Murray Schafer "to dramatize the aberrational effect" of the developments of the 2oth century (Schafer 1977: 77, 273). The term, deliberately loaded with heavy connotations, can be reinterpreted as a reaction towards the widely popular background music business of the 1970s.

Displacing sounds electro-acoustically has changed the soundscape and listening profoundly. However, the effects are not only the negative ones to which schizophonia seems to be referring. It can be assumed that the term is not meant to criticise the detachability of sound per se, but more likely the reckless use of these sounds. Ethnomusicologist Steven Feld has pointed out that schizophonia cannot be understood as a major transformation in the history of technology, but as practice, and he introduces the concept of schismogenesis to describe "progressive mutual differentiation" (Feld 1995: 107) which can be found in issues such as musical ownership, fandom and musical styles. 
Another concept inspired by Schafer's idea, but which differentiates itself from the scholarly legacy and connotations of it, is transphonia (Uimonen 2005: 63). Drawing from schismogenesis, it underlines the processual nature of restated sounds, particularly when studying the reception of music. Transphonia refers to the mechanical, electroacoustic and digital storing, moulding, reproducing and transmitting of sounds. Most of all, it pays scholarly attention to past and current music performance practices in light of multiple individual and social meanings compared to the original contexts of the sounds. Thus, compared to the pre-phonographic era, music today can have multiple meanings, depending on where one listens to it.

The popularity of transphonic equipment not only advocates background listening, but it also increases attentive listening. Phonographs, gramophones, radios, compact cassette players, transistor radios, digital recordings and playback devices have all enabled music listening in an increasing variety of places and spaces. As a result, whereas once music listening was confined by technological limitations, nowadays, both background and foreground music have become an inseparable part of the contemporary urban sonic environment. That music is part of the sonic environment is seldom questioned, and music reception ranges from going unnoticed and ignored to the creating conflicts and friction among urban dwellers. Among the first scholars to notice this was Shuhei Hosokawa (1981), who, in the context of writing a short history of mobile music, stated that in urban environments, there are no clear frontiers for music and noise, noting "most of this music is made involuntarily or without motive - without any conscious aesthetic motivation".

New ways of consuming musical sounds are closely related to the concept of ubiquitous listening, as well as how music is connected to genre-normative ways of listening. Music scholar Anahid Kassabian writes how modes of listening, listening situations and music styles are co-producing each other. Most of the music that we hear daily is intended to be listened to inattentively, and it is often selected by someone other than ourselves. This poses challenges to music studies: if contemplative listening has created a canon of Western classical music, are there other canons and repertoires created by other modes of listening? (Kassabian 2002: 131-135.) 
Kassabian's question can be answered and studied in detail with the help of commercial radio music policies. The everyday music content of the station is not supposed to disturb radio listeners, but at the same time, it must be interesting enough to create a cosy background to make daily chores more endurable. If a station does not succeed in fulfilling these expectations, they assume the audience will switch to another channel. To avoid this, in creating their music canons, radio channels are testing their music content before broadcasting it to please the tastes of their audience. All this should be considered when studying radio music culture, which is defined as all practices that have an effect on music broadcast on the radio including process of acquiring music, music selection, and the governing of music. (Uimonen 2011: 18-19, 23.)

To some extent, cultural conventions and ideas about how classical music, rock, folk or any music is supposed to be listened to or danced to lose their meanings in the context of ubiquitous music. Although almost any genre can be classified as ubiquitous music, this is not to say that ubiquitous music can be any kind of music or that selecting it would be an indifferent act. On the contrary, switching the background music of a gym with that of a fine-dining restaurant would most likely lead to undesired results for both locations (see also Boschi, Kassabian \& Quiñones 2013).

In addition, consuming ubiquitous music requires contextual listening skills and competence to act in various acoustic environments. A musical work can be listened to attentively in a concert hall, but it is understood that the same contemplative attention given to a piece of music from a car stereo or Walkman might become a safety risk for the listeners and their fellow commuters.

\section{Radio music in an urban environment}

Although we perceive spaces as physical, they all have sounds, be they music or sounds considered part of the environment (Boschi, Kassabian \& Quiñones 2013: 11). The urban public space is understood here as something that is shared and that is in constant transformation, also sonically (Kytö 2013: 20-22). This suggests that a space composed of electroacoustic sounds would be in constant transformation, too, and it would be a target of constant negotiations and strug- 
gles regarding its nature, e.g. in relation to the genders, classes, ages and socioeconomic statuses of its users.

Commercial radios are constructing playlists in accordance with their music culture and making them available for anyone who wants to take advantage of this ready-made product at home, in the workplace or in any other acoustic environment. They have an outstanding effect on moulding diverse public environments in Finland, as well. The Finnish Composers' Copyright Society Teosto has carried out studies on how much, in what premises and under which situations background music is being used. Diverse spaces include accommodation facilities, buses, coaches, customer premises, outdoor spaces, restaurants, cafes, sports halls and tracks, staff premises, taxis, gyms, exercise classes, telephone hold music and so on. In 2012, Teosto had nearly 30000 customers using background music (Uimonen 2009: 61; Teosto 2013) and they were divided as follows:

\section{CUSTOMERS USING BACKGROUND MUSIC IN 2012 \\ TOTAL 29950}

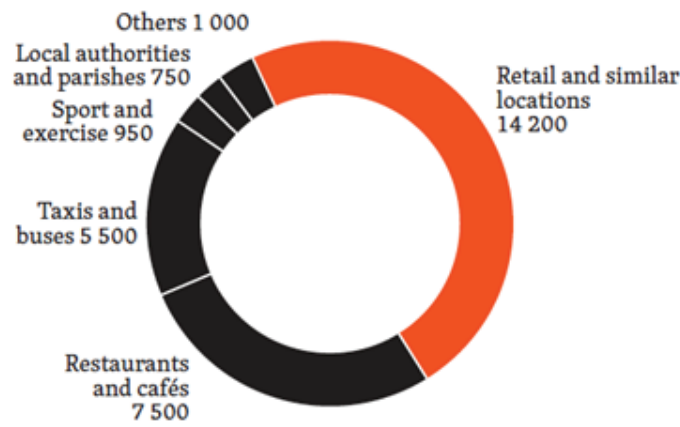

Diagram 1. Customers using background music in 2012 (Teosto 2012: 42).

Yearly surveys provide data that are more detailed on the music used, including customer preferences. According to a survey conducted in 2012, over 76 per cent of enterprises were using the radio for background music. The radio was pre- 
ferred by hairdressers, barbers, shops and taxis, whereas restaurants preferred other sources of music. In addition, 50 per cent of the respondents considered background music important, as it covered the uneasy silence and the hums of the machinery and enabled confidential discussions (Uimonen 2009; Teosto 2012).

Radio use is monitored not only in public spaces but also in private premises. In Finland, radio listening is being evaluated by Kansallinen Radiotutkimus (National Radio Survey). The informants participating in this survey complete diaries stating when, where, how much and to which channel they are listening. The listening sites listed in the diary include the home, car, work and 'other'. Public transportation is not included, due to the challenging listening environment, as it cannot be verified whether a bus commuter is receiving the advertiser's message, which makes radio advertising a futile investment (Uimonen 2009: 65; KRT 2015). Information on listening to the radio on a bus or in other public spaces is not collected, which is somewhat peculiar considering the strong opinions on the matter. To put it bluntly, the urban space is very much constructed by music that is not meant to be listened to, at least according to some users of these spaces.

However, it should be noted that not only radio music but also specially ordered background music is used in different public spaces. This alternative is being chosen when companies want their customers to stay at their premises for a relatively long time, such as at enterprises selling luxury cars. Also, companies find it undesirable to expose customers to radio advertisements from competing enterprises. In addition, music is found to be more desirable than radio talk. The placed order is not completed before the customer has given feedback to the producer on the music and the producer has made the necessary adjustments (Uimonen 2009: 69). Quite interestingly, the feedback might include a wish for the repetition of an individual song - a wish that has been clearly affected by commercial radio station music policies in broadcasting hit tunes recurrently, which have changed the standards regarding how contemporary foreground music should sound. 


\section{On becoming ubiquitous: standardised radio music contents}

As the urban environment consists of electroacoustic musical sounds, it raises the question regarding what the criteria are for music to become ubiquitous and, more precisely, who is responsible for defining these criteria and in the end making the actual music selection. The contemporary radio music selection process is carried out according to given standards, which involve several individual tasks before music is actually broadcasted. The outcome of this automated process is a playlist, which is targeted to radio listeners.

Opposed to European public service radio, American style commercial radio is predominantly built on advertising and music. Nevertheless, it is not the advertised consumables or services that are being sold to listeners so much as the listeners are sold as prospective audiences to advertisers manifested as ratings (Smythe 1981: 27). Most format radios use selected music genres to attract an audience and maintain them as loyal listeners of the station. The success or failure of a station is measured in its ability to fulfil the genre expectations of a radio listener.

To meet the listener's expectations and to select the right kind of music, the radio consultants launched auditorium music testing in the 1990s. Later, the tests were supported by data supplied through Internet questionnaires. During auditorium music testing, less that ten-second samples of familiar music are played to an audience consisting of 200 listeners, who belong to the target group of the station. Usually, between 500 and 600 individual samples are evaluated in one session. The test is followed by selecting, classifying and placing the individual songs on a radio playlist with the help of music programming software. The locations and the time of day are considered crucial while selecting songs; the listening rates are highest in passenger cars at commuting hours 8:00 and 17:00 and at the work place in the morning and in the afternoons (Uimonen 2011; ARH 2015).

The auditorium tests as an empirical method were already being criticised by music sociologist Theodor W. Adorno (1906-1969) in the 1940s. Although some of his critical arguments on popular music may not necessarily hold in the contemporary media environment, his concepts and notions are still applicable, especially in the radio music context. The strength of Adorno's arguments is further enhanced by his personal encounters with music testing in commercial settings. 
Adorno's experience with American-style radio was based on his occupation in the radio music programming division at the Princeton Radio Research Project in 1939. Contrary to the goals of the radio project, he was not interested in classifying facts and making them available as information, but instead in interpreting phenomena. Adorno considered the listener response survey results to be superficial and more ideological than empirical: for instance, the division of the musical experience into classical and popular is a "final one, somehow part of the natural order of things" (Leppert 2002: 217). In addition, in his memoir of his American experience, Adorno describes a machine that allowed the listener to indicate his or her likes and dislikes during the musical performance by pushing a button, which measured "mere stimulus" (Leppert 2002: 213-217).

There is little or no doubt that this machine was a predecessor of the equipment used in contemporary auditorium tests launched in 1990s Finland, where participants were required to use a dial to select their preferences from different fragments of music. According to the Scandinavian Broadcasting Systems music director, the listeners were asked to evaluate the music fragments by selecting from among a few alternatives ("love it" / "like it/"oK/"dislike it" / "hate $\mathrm{it}^{\prime \prime}$ / "bored of it"), and they were also asked whether they thought that a given song was broadcast too recurrently (Uimonen 2011: 197; see also ARH 2015). The alternatives presented in the auditorium test are parallel to Adorno's critical comments on "mere stimulus". They were selected to support the company's corporate culture instead of to collect information for a more profound analysis and to interpret the phenomena in a wider context, which, of course, might not be in the best interests of the owners of an economically prosperous radio station in the first place.

Nevertheless, contemporary auditorium music testing that serves commercial radio music policies can be interpreted as standardisation and pseudo-individualisation. According to Adorno's critical view, "standardization of song hits keeps the customers in line by doing their listening for them, as it were. Pseudoindividualization, for its part, keeps them in line by making them forget that why they listen is already 'pre-digested'" for them. (Adorno 2002 [1941]: 445.) Indeed, during the auditorium tests, new music is not evaluated, only songs already familiar to listeners, i.e. "standardized musical goods". Because auditorium music testing consists of familiar songs, it is evident that the ability of the listener to 
recognise samples of such songs has been a method for constructing radio music content successfully for over 70 years now.

Adorno considered that the production of popular music could be called "industrial" only in its promotion and distribution. The production of popular music is centralised in economic organisations; the act of producing a hit song is still handcrafted and individualistic (Adorno 2002 [1941]: 443). These two aspects of producing a popular song in the contemporary media environment are not necessarily exclusive of each other, as popular music producers had already begun to consider Top 40 radio format requirements in the late 1950 os to ensure their songs were broadcasted. In commercial radio, the industrial aspects are explicit, as they involve both promoting and distributing popular music. The radio music culture in turn shapes the act of producing or composing a hit song, because the artists and individual songs must fit with the radio channel's sound to be broadcast. As a result, standardisation is carried out at least twice: first in music production, when a tune is being composed, written and arranged, and second in the auditorium, where music is being selected to or excluded from a radio station's playlist.

Adorno's Marxist stance was that the customers of musical entertainment are objects or products of the same mechanisms, which determine the production of popular music: "Their spare time serves only to reproduce their working capacity. It is a means instead of an end" (Adorno [1941] 2002: 458). Standardised music and the evolution of music dissemination have changed the sites of listening to the extent that radio music - or any music from any transphonic source for that matter - is being listened to while working or engaging in other activities. Reproducing the working capacity is thus already carried out while listening to music. The music selection process further underlines this: radio content is not allowed to irritate the listener to the extent that the task it accompanies would be interrupted. Rhythm and tempo among other parameters are being constantly evaluated to produce a sense of continuity without "killing the flow", which the sBs Discovery Radio producer pointed out as criteria for compiling the playlist (Uimonen 2011: 199).

Adorno's contemporary, philosopher Walter Benjamin, although not a music scholar himself, would perhaps be willing to take more emancipatory view on the matter: mechanical reproduction also enabled new functions and meanings for cultural products (see Middleton 1990: 64-65). His interpretation would stress 
the "liberating tendencies" of mass production, so radio listeners could perhaps make their work more interesting or entertain themselves while working (Leppert 2002: 245).

The electroacoustic construction of the urban sonic environment by a radio broadcast is the result not only of radio's production culture but also its standardised music selection process. The transformation of the soundscape is influenced also by changes in a radio channel's ownership, when it merges to larger units or when it is chained due to a corporate acquisition. This in turn gradually changes the radio channel's music policies, as well. As a result, an individual music selection process carried out in a specific place for a limited number of listeners is extended to several towns and cities, as presented in a following chapter. An individual radio station, Radio 957, is given as an example.

\section{A radio station's expanding acoustic space}

Radio 957 started broadcasting on 15 August 1985. With a licence granted to the Student Union of the University of Tampere, it was targeting its programmes to all Tampere region residents, not solely to students or music lovers. Diverse music genres and artists were broadcast in individual programmes selected by individual show hosts, also during the daytime. In the early 1990s, Radio 957 faced serious financial problems when two competitive licences were granted in their broadcasting range. As a result, another company, Radio Sata acquired 75 per cent of Radio 957's shares in 1992. This is also when the two radio stations began to plan their music contents in close collaboration (Uimonen 2011: 149; see diagram 2).

Radio Sata was also the company that introduced American-style format radio to Finland. Its personnel consulted several local and semi-nationals stations, such as Kiss FM/Voice, thus having a profound effect on the contents of radio broadcasts throughout the country (Uimonen 2010). Among other radio stations, both Radio 957 and Radio Sata were later acquired by multinational Scandinavian Broadcasting Systems, which in due time was acquired by the Prosiebensat I media conglomerate. In December 2012, the SBS Nordic ProSiebenSat 1 Group was acquired by Discovery Communications for the total sum of 1.3 billion euros and 
the deal included several television and radio stations (HS 2012). Finally, while writing this article, yet another corporate acquisition took place, when Bauer Media sealed a deal for the takeover of SBS Discovery Radio (D 2015). Currently, Radio 957 and Radio Sata are broadcasting in several Finnish towns with identical musical content and they were renamed together as Radio City (see diagram 2).

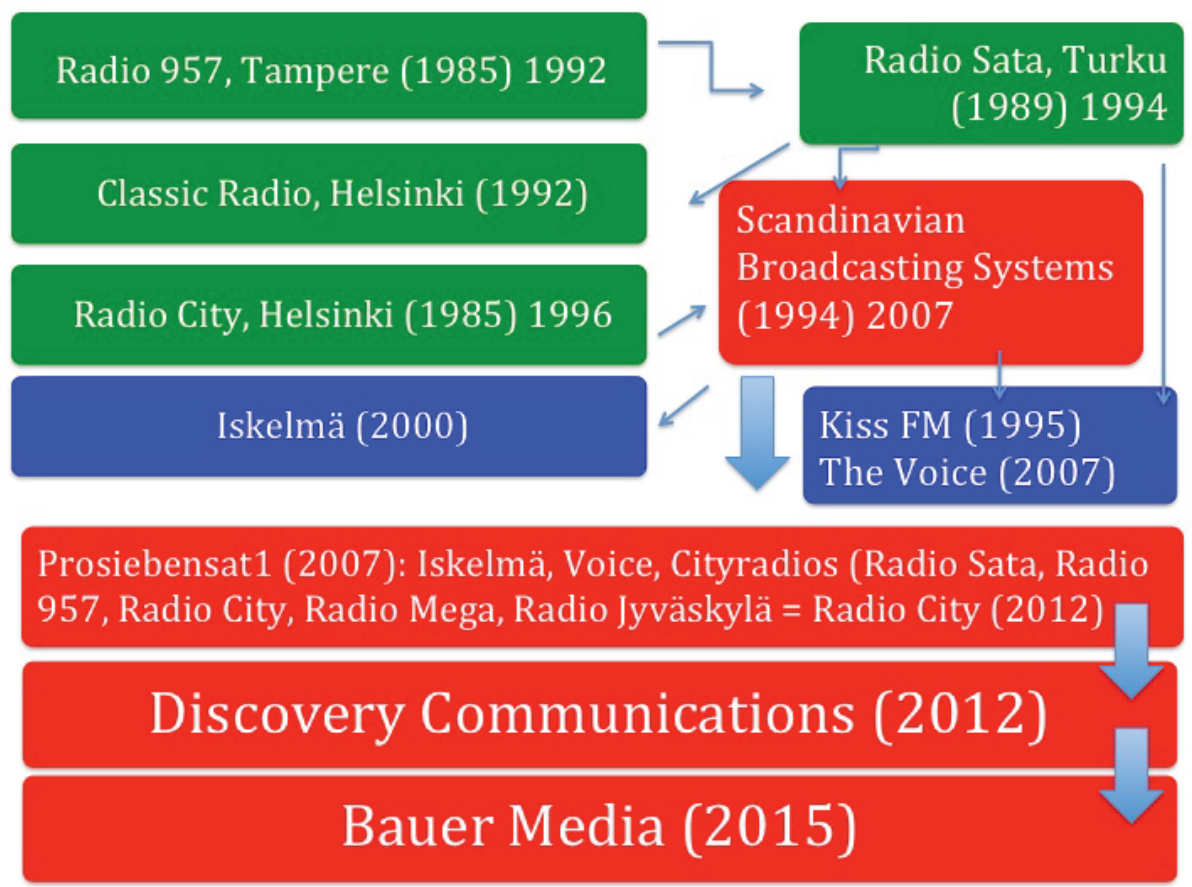

Diagram 2: Radio 957 (1985-2015) ownership changes.

According to a 2005 study on the relationship between locality and radio news, Radio 957 was targeting its news to males between 30 and 45 years old. The target group was personified as an imaginary person, "Masa kolkytkuus vee" (36-yearold Masa), whose family, personal history, hobbies, line of work and musical taste were constructed with the help of marketing research (Siljamäki 2006: 39; Uimonen 2011). This model of virtual listeners was used also in public service 
radio, such as ввс ("Dave \& Sue"). The practice was criticised because in this way, the same songs ended up being aired by stations targeting the same demographic group (see Uimonen 2010: 11).

What was 36-year old Masa listening to, then? The news content targeted to him was evaluated in January 2005, so it was reasonable to select music broadcast from the same period (Uimonen 2009). The monitoring day selected is Tuesday 18 January 2005, providing data to reconstruct the music content aired on an ordinary work day. Radio 957 was broadcasting rock, adult contemporary/pop and suomirock (Finnish rock-schlager) the most, followed by blues, soul, rhythm \& blues, country, iskelmä (Finnish schlager) and dance (hip hop, electronic dance music). The overall channel sound of Radio 957 was characterised by rock, adult contemporary/pop and suomirock, which comprised 8o per cent of their musical content. Classical music, religious music, folk and jazz were not aired.

Music targeted to 36-year-old Masa has not really changed during the years when evaluated by random samples. On Tuesday 13 September 2005, the same artists dominated the broadcasts; in addition, five years earlier on to January 2000, the playlist looked familiar. Again, five years before that, on 13 January 1995, Radio 957 broadcast mainly well-known artists and their hits (Uimonen 2009: 77-80).

Over 15 years, rock music of the 1960s and 1970s was represented by the hits of the Beatles, Dire Straits, Creedence Clearwater Revival, The Rolling Stones, Marvin Gaye and Sam Cooke; that of the 1980s and 1990s was represented by Bon Jovi, Guns ' $n$ ' Roses, Queen, Red Hot Chili Peppers, Bruce Springsteen and Toto; adult contemporary and pop were represented by Abba, Madonna, The Rubettes and Bonnie Tyler, with a third of the music content performed in the Finnish language or produced in Finland. It is no surprise then that the contemporary playlist of Radio 957, now renamed Radio City, reveals that on 13 January 2015, its music content again consisted of familiar songs from familiar artists, such as The Beatles, Dire Straits, Creedence Clearwater Revival and The Rolling Stones (Uimonen 2009: 77-80; B 2015). 


\section{A middle-aged man's alleged musical taste and public commuting}

A commercial radio station's content is crystallised during the morning and afternoon commuting hours. This is when radio stations are reaching most of their audience, which can then be delivered to the advertisers as rating numbers. Analysed data provided by IFPI shows that Radio 957/Radio City's playlist transformed relatively little over the years. To some extent, the music content has remained the same for over a decade when evaluated diachronically and especially when evaluated by musical contents during the commuting hours.

A radio station must distinguish itself from its competitors in the way it sounds. Preferably, the audience should identify it by only listening to broadcast music. However, it is not only the music but also the advertisements, parlance and jingles that construct the overall channel sound of a radio station (Uimonen 2011: 31). The outcome of this selection process is the sonic construction of the commuting city dwellers' daily life.

How then may the data regarding music broadcasts by Radio 957/Radio City be contextualised to the public acoustic environment in Tampere and, more specifically, on public transportation? At the time of this research, the transphonic environment created by the aforementioned radio station was dominated by Anglo-American popular music and suomirock. This is partly explained by the selected target group of the station, but also by economic factors: instead of domestic releases, broadcasting American music is more cost effective, as the United States has not signed The Rome Convention for the Protection of Performers, Producers of Phonograms and Broadcasting Organisations (Uimonen 2011: 64).

Music on public transportation raised public debate in 2001 in the local newspaper, Aamulehti.

The letters to the editor against radio music on buses are as follows: pseudonym Decibel Meters to Buses did not want to hear "any suomipop because it makes my ears hurt". The Silent Wanderer of the Earth criticised "music pollution" on buses and in stores and received moral if not moralising backup from the pseudonym The One who Appreciates Silence. The writer suggested that some individuals were incapable of enduring silence, which is the reason why their lives are filled with "ice hockey, beer, Fi car races and other circus". Mami felt that riding the bus was like attending to a rock festival, where all were "forced to listen to 
the bestial music". Mami received support from Passenger on Bus Nr. 2, who had suffered from the bus driver's preferences and "believed" that other passenger were suffering from it, too (Uimonen 2009: 80).

The counter arguments included that music on a bus is a privilege to all passengers, and an individual complainant will ruin the journey for everyone. In addition, it was claimed that music has a soothing effect for passengers (Pseudonym Play the pop machine and Mr. Mikko Vuorinen). The press officer of the City of Tampere was commenting on the letters to the editor by referring to the job satisfaction of the driver. She also pointed out that if there is a single passenger who wants to have the radio switched off, his or her wish is to be respected (Uimonen 2009: 81).

It can be assumed that the acoustic space is well defined in advance, leaving hardly any room for negotiations. A case study on Radio 957/Radio City's music content over a period of 20 years provides data to sketch out the sonic environment not only in Tampere, but also in other towns belonging to the same radio chain. The data enables a detailed reconstruction of the acoustic environment of public transportation. In case a bus driver had tuned the radio receiver to Radio City's frequency, the commuters travelling on a local bus in Tampere on 13 January 2015 during the morning and afternoon rush hours (8.00-9.00 and 16.00-17.00) were exposed to 37 songs, including the artists described above. Furthermore, they were exposed to 36-year-old Masa's alleged music preferences, although it remains unclear to what extent Masa himself uses public transportation.

\section{Conclusion}

The worldview found in Finnish schlager and folk traditions is founded on immutability and ritualistic repetition that connotes the safe continuity of life (Jalkanen 1992: 15). The same stability can be found in suomirock and Anglo-American rock music, especially in the ways they are used in commercial radio music culture. The unchanging routines are maintained in repetitious tunes, excluding the music of other cultural genres, that radio stations' target groups might find unpleasant or dull: morning rush hour commuting does not go together well with subversive or unfamiliar music content. However, it remains to be answered 
how this music selection and its ritualistic nature would be evaluated if the everyday experiences of the urban dwellers and commuters were considered.

The physical environment created by urban planners, architects and construction companies sets the stage for the acoustic urban environment. Ideologically, public space is appropriated by the values of the radio station, which manifest sonically in broadcast music. Negotiations considering radio music and urban space are also related to issues of gender and class, which are underlined by the case study showing that radio music contents are selected in accordance with demographic and other factors related to the radio stations' target groups.

This space is partly constructed and transformed by the radio stations' music culture policies, relying on tested music contents as proven by IFPI Finland statistics and interviews. The study was contextualised with notions of commercial radio, as described by Theodor Adorno. Whilst his notions on the culture industry and popular music have been criticised, in the context of contemporary radio music content, his understandings of standardisation retain their relevance.

Commercial and public service radio stations are offering ubiquitous music or any other contents for anyone who wishes to use them. These standardised products are designed to function properly in various acoustic environments, whether at home, in the workplace or in a vehicle used for commuting. However, listening to the radio becomes a negotiable issue when several people are exposed to the music. As previously mentioned, not all transphonic or ubiquitous music fits into all acoustic environments. Further evidence was offered by the letters to the editor, where pros and cons of playing music on public transportation were pondered. According to this, commuters and other city dwellers are seemingly constructing their acoustic environments not only concretely by their activities but also symbolically by talking and writing about them, including transphonic phenomena, such as ubiquitous music.

Radio music in urban public spaces is largely a side effect of the radio stations' music contents, as their music is not compiled with these places in mind. Regardless, it is evident that the stations are relatively powerful in constructing the sonic environments of shared spaces. This construction is in the hands of a few radio professionals, although it should be noted that their position is far from being monolithic but negotiable under the constantly changing economic, legislative and cultural circumstances. 
A case study of Radio 957 shows evidence of consolidating radio industry's effects on canonised ubiquitous music and its dissemination. Originally limited to the immediate locality of its transmitter, music content in question gradually changed the sonic environments semi-nationally in several urban areas in different parts of the country. This means that when a systematic study in urban public spaces is addressed in the future, a few basic factors should be considered. These should include the historical and contemporary changes in the economy, music culture and, hopefully, urban planning. When transphonic sounds in general and radio music in particular are constructing shared urban environments, it is reasonable to call for urban planning in which the electroacoustic design would perhaps be as equally attended to as any other acoustic design, especially now, when contemporary media and the technological environment enable diverse and multifaceted opportunities. 


\section{References}

Adorno, Theodor W. (2002 [1941]) “On Popular Music". Essays on Music. Ed. Richard Leppert.

Berkeley: University of California Press. Pp. 437-469.

ARH (2015) American Radio History. Radio Music Research. Auditorium Music Testing.

http:/ / www.americanradiohistory.com/research_A MT.htm (accessed 23.2.2015).

B (2015) Biisit.info. Tietää mikä radiossa soi Tune info. Knows what is being broadcast].

http:/ / biisit.info (accessed 23.2.2015).

Boschi, Elena, Kassabian Anahid \& Quiñones, Marta García (eds) (2013) Ubiquitous Musics. The Everyday Sounds That We Don't Always Notice. Farnham: Ashgate.

D (2015) The Drum. Bauer Media seals deal for Nordic broadcaster sBs Discovery radio. http://www.thedrum.com/news/2015/04/28/bauer-media-seals-deal-nordic-broadcastersbs-discovery-radio (accessed 2.5.2015).

Feld, Steven (1995) "From Schizophonia to Schismogenesis: The Discourses and Practices of World Music and World Beat". The Traffic in Culture: Refiguring Art and Anthropology. Eds George E. Marcus \& Fred R. Meyers Berkley. Los Angeles: University of California Press. Pp. 96-126.

Hosokawa, Shuhei (1984) The Walkman Effect. Popular Music 4 (1), pp. 165-180.

HS (2012) Helsingin Sanomat. Kaksi suomalaista tv-kanavaa ja useita radiokanavia Discoverylle [Two Finnish television channels and several radio channels acquired by Discovery] 14.12.2012.

Jalkanen, Pekka (2002) Pohjolan yössä. Suomalaisia kevyen musiikin säveltäjiä Georg Malmsténista Liisa Akimofiin [In the Northern Night. Finnish popular music composers from Georg Malmstén to Liisa Akimof]. Helsinki: Kirjastopalvelu.

Kassabian, Anahid (2002) “Ubiquitous Listening”. Popular Music Studies. Eds David Hesmondhalgh \& Keith Negus. New York: Oxford University Press. Pp. 131-142. KRT (2015) Kansallinen radiotutkimus [National Radio Survey]. http:/ /www.finnpanel.fi/en/ radio.php (accessed 23.2.2015).

Kytö, Meri (2013) Kotiin kuuluvaa: yksityisen ja yhteisen kaupunkiäänitilan risteymät [Sounds like home. Crossings of private and common urban acoustic space]. Joensuu: University of Eastern Finland.

Leppert, Richard (2002) "Culture, technology and listening. Commentary". Theodor W. Adorno. Essays on Music. Selected, with Introduction, Commentary, and Notes by Richard Leppert. Berkeley: University of California Press. Pp. 213-250. 
Middleton, Richard (1990) Studying Popular Music. Milton Keynes: Open University Press.

Schafer, R. Murray (1977) The Tuning of the World. Toronto: McCelland and Stewart Limited.

Siljamäki, Anna-Maria (2006) Tiivistetty paikallisuus: Radio 957:n paikallisuuden tarkastelua uutisten avulla. [Condensed Localism. Radio 957's Localism Analysed in Context of the News].

Tiedotusopin pro gradu -tutkielma, Tampereen yliopisto. [Ma Thesis, University of Tampere].

Smythe Dallas W. (1981) Dependency Road: Communication, Capitalism, Consiousness, and Canada. New Jersey: Ablex Publishing.

Teosto (2012) Teosto. Annual Report. Helsinki: Teosto.

Teosto (2013) Teosto. Background music. Price list. http:/ / www.teosto.fi/en/teosto/articles/ background-music-pricelists (accessed 23.2.2015).

Uimonen, Heikki (2005) Ä̈̈ntä kohti. Ääniympäristön kuuntelu, muutos ja merkitys [Towards the Sound. Listening, change and the meaning in the sonic environment]. Acta Universitatis Tamperensis 1110. Tampere: Tampere University Press.

Uimonen, Heikki (2009) "Haitaribussi. Kaupallisen radiokanavan musiikkivalinnat ja kaupunkitilan äänellinen rakentuminen" [Accordeon bus. The music policies of commercial radios and the making of urban sonic environment]. Julkisen tilan politiikkaa ja poetiikkaa. Tieteidenvälisiä otteita vallasta kaupunki-, media- ja virtuaalitiloissa. [The Politics and Poetics of Public Space. Interdisciplinary Views on Power in Urban, Media and Virtual Spaces]. Eds Seija Ridell, Päivi Kymäläinen \& Timo Nyyssönen. Tampere: Tampere University Press. Pp. 6o-91.

Uimonen, Heikki (2010) Towards Streamlined Broadcasting. The Changing Music Cultures of 1990s Finnish Commercial Radio. IASMP@ vol.1, No 1.

http:/ / www.iaspmjournal.net/index.php/IASPM_Journal/article/view/256/545 (accessed 23.2.2015).

Uimonen, Heikki (2011) Radiomusiikin rakennemuutos. Kaupallisten radioiden musiikki 1985-2005

[The Structural Reform of Radio Music. Commercial radio music contents 1985-2005 in Finland]. Tampere: Tampere University Press. 